\title{
Enzyme inhibitory and immunomodulatory activities of the depsidone lobaric acid extracted from the lichen Heterodermia sp.
}

\author{
Vinitha M. Thadhani ${ }^{1 *}$, Qamar $\mathrm{Naaz}^{2}$, M. Iqbal Choudhary ${ }^{2}$, M. Ahmed Mesaik ${ }^{3}$ and \\ Veranja Karunaratne ${ }^{4}$ \\ ${ }^{1}$ Department of Chemistry, Faculty of Applied Sciences, University of Sri Jayewardenepura, Gangodawila, Nugegoda. \\ ${ }^{2}$ H.E.J. Research Institute of Chemistry, International Centre for Chemical and Biological Sciences, University of Karachi, Pakistan. \\ ${ }^{3}$ Dr. Panjwani Centre for Molecular Medicine and Drug Research, University of Karachi, Pakistan. \\ ${ }^{4}$ Department of Chemistry, Faculty of Science, University of Peradeniya, Peradeniya.
}

Revised: 07 October 2013; Accepted: 11 December 2013

\begin{abstract}
This study evaluates the enzyme inhibitory and immunomodulatory activities of the lichen specific depsidone, lobaric acid. Lobaric acid was extracted with methanol from Heterodermia sp. found in Labukelle, Sri Lanka with a yield of $0.67 \%$. It was subjected to enzyme inhibition assays using acetyl and butyryl-cholinesterase, phosphodiesterase, $\beta$-glucuronidase, $\alpha$-glucosidase and urease. In the $\beta$ - glucuronidase inhibitory activity it showed an $\mathrm{IC}_{50}$ value of $3.28 \pm 0.05 \mu \mathrm{M}$, which was significantly lower than that of the standard, D-saccharic acid 1, 4-lactone $\left(\mathrm{IC}_{50}=48.4 \pm 1.2 \mu \mathrm{M}\right)$. Lobaric acid showed a significant inhibition of phosphodiesterase enzyme with an $\mathrm{IC}_{50}=313.7 \pm 2.2$, when compared with the two standards EDTA $\left(\mathrm{IC}_{50}=274.0 \pm 0.1 \mu \mathrm{M}\right)$ and cysteine $\left(\mathrm{IC}_{50}=748.0 \pm\right.$ $0.1 \mu \mathrm{M})$. Lobaric acid showed a moderate actyl and butyryl -cholinesterase inhibitory activity while it showed no activity against the enzymes $\alpha$-glucosidase and urease.
\end{abstract}

In the immunomodulatory assay, lobaric acid exhibited a potent oxidative burst inhibitory activity in human polymorphonuclear $(\mathrm{PMN})$ cells. It suppressed both the myloperozidase dependant and myloperozidase independent reactive oxygen species (ROS) production of PMNs. The results indicate the pharmacological potential of lobaric acid as a lead compound for further studies.

Keywords: $\beta$-glucuronidase, enzyme inhibitory activity, Heterodermia sp., immunomodulatory activity, lobaric acid, phosphodiesterase.

\section{INTRODUCTION}

Lichens are a rich source of bioactive secondary metabolites (Mitrovi'c et al., 2011). Previous studies have reported a number of compounds including the Ambewela amide A, B, sekikaic acid and lecanoric acid from Sri Lankan lichens such as Parmotrema sp., Pyxine consocians and Heterodermia leucomelos with anticancer, antioxidant, $\alpha$-PLK1 inhibitory and insect herbivoury activities (Karunaratne et al., 2002, 2005, 2008; Kathirgamanathar et al., 2006; Thadhani et al., 2011; Williams et al., 2011). Of the major structural classes of lichen metabolites, depsidones comprise a tricyclic ring system with two benzene rings connected through ether and ester moieties and are relatively rare. The depsidone lobaric acid is one of the most biologically potent secondary metabolites reported from lichens such as Stereocaulon sasakii, Stereocaulon alpinum Laur and Sterocaulon azoreum (Morita et al., 2009).

Various biological activities of lobaric acid have been reported earlier including antitumor, antiproliferative (Burlando et al., 2009), anti-inflammatory, antioxidant (Thadhani et al., 2011), antimicrobial (Thadhani et al., 2012) and selective serine threonine protein kinase (PLK1) inhibitory activity. Lobaric acid inhibits the 5-lipoxygenase pathway by inhibiting the formation of cysteinyl - leukotrines as determined by enzyme immunoassay (Gissurarson et al., 1997). The antimitotic activity of lobaric acid has also been studied and it has been shown to inhibit the polymerization of tubulin (Morita et al., 2009). Through interaction with a dynamic surface of the CBP/p300 GACKIX domain, lobaric acid demonstrated an enormous potential for targeting difficult protein-protein interactions (Majmudar et al., 2012; Stojanovic et al., 2012). Furthermore, it has

*Corresponding author (vinimool@yahoo.com) 
been reported that lobaric acid elicit contact allergy in sensitive persons (Thune \& Solberg, 1980).

In this study, the pharmacological potential of lobaric acid, particularly its immunomodulatory and inhibitory activities against $\beta$ - glucuronidase, acetyl - and butyrylcholinesterases, phosphodiesterase, $\alpha$-glucosidase, and urease enzymes are reported.

\section{METHODS AND MATERIALS}

Manually cleaned, air-dried and crushed lichen specimens of a Heterodermia sp. collected from Labukelle, Sri Lanka were sequentially extracted with $\mathrm{CH}_{2} \mathrm{Cl}_{2}$ followed by $\mathrm{MeOH}$. Lobaric acid was isolated with a yield of $0.67 \%$ from the $\mathrm{MeOH}$ extracts when fractionated via silica gel column using hexane/ $\mathrm{CH}_{2} \mathrm{Cl}_{2}$ to $\mathrm{CH}_{2} \mathrm{Cl}_{2} / \mathrm{MeOH}$ as solvents. The dentification of the compound was carried out by using spectral data and its comparison with the reported data (Gonzilez et al., 1992).

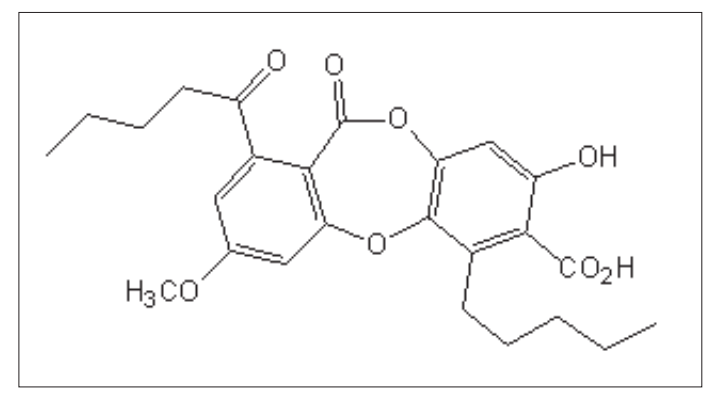

Figure 1: Structure of lobaric acid

To determine the inhibitory activity of lobaric acid on acetyl and butyryl-cholinesterases enzymes, electric-eel acetyl-cholinesterase (AChE, EC 3.1.1.7) and horse serum butyryl-cholinesterase (BChE, EC 3.1.1.8) were used. The inhibition was measured using the spectrophotometric method developed by Ellman et al. (1961).

$\beta$-Glucuronidase inhibitory activity was determined by measuring the absorbance of $p$-nitrophenol at $405 \mathrm{~nm}$, formed from the substrate $p$-nitrophenyl- $\beta$-D-glucuronide on addition of $\beta$-glucuronidase in the presence of lobaric acid (Khan et al., 2002).

Phosphodiesterases enzyme inhibitory activity was measured by a spectrophotometric method using bis-( $p$-nitropheny1) phosphate as chromogenic substrate, which was added to a mixture containing a buffer, phosphodiesterase enzyme and the test compound lobaric acid. The release of $p$-nitrophenol was measured at $410 \mathrm{~nm}$.
Lobaric acid was evaluated for its $\alpha$-glucosidase inhibitory activity using the method of Oki et al. (2000) and against the urease enzyme using the indophenols method (Weatherburn, 1967).

Lobaric acid was screened over a range of concentrations $(3.1-50 \mu \mathrm{g} / \mathrm{mL})$ for its oxidative burst inhibitory potential. The measurement of chemiluminescence was employed to investigate the different kinds of reactive oxygen species $\left(\mathrm{OH}, \mathrm{O}^{-2}\right.$ and $\mathrm{H}_{2} \mathrm{O}_{2}$ ). Luminol-enhanced chemiluminescence assay was performed as described by Helfand et al. (1982). Briefly, whole blood neutrophils and polymorphonuclear leukocytes (PMNs) were suspended in Hank's balance salt solution (HBSS) with calcium and magnesium salts and incubated with lobaric acid for $30 \mathrm{~min}$. To each well, serum opsonized zymosan (Saccharomyces cerevisiae origin) was added, followed by the addition of luminol (3-aminophthalhydrazide), and then HBSS to adjust the final volume to $0.2 \mathrm{~mL}$. HBSS was used as a control. Chemiluminescence peaks were recorded with a luminometer.

\section{RESULTS AND DISCUSSION}

Cholinesterase inhibitors are used for the management of Alzheimer's disease. Lobaric acid showed moderate inhibition against acetyl-cholinesterase with an $\mathrm{IC}_{50}$ value of $26.86 \pm 0.9 \mu \mathrm{M}$ and butyryl-cholinesterase with an $\mathrm{IC}_{50}$ value of $36.76 \pm 0.8 \mu \mathrm{M}$, when compared to the standard gallanthamine (AChE: $0.50 \pm 0.01 \mu \mathrm{M}$ and BChE: $8.50 \pm 0.01 \mu \mathrm{M})$. It has been reported that acetylated derivatives of depsidones isolated from Lobaria pulmonaria (L.) Hoffm. (Lobariaceae) possess moderate acetyl-cholinesterase inhibitory activity (Mortia et al., 2009). This is the first report on AChE and BChE inhibitory activity of lobaric acid.

In certain diseases such as cancer, inflammatory joint disease, some hepatic diseases and AIDS, the activity of $\beta$-glucuronidase increases. An $\mathrm{IC}_{50}$ value of $3.28 \pm$ $0.05 \mu \mathrm{M}$ was observed, which is 12 fold more potent than the standard D-saccharic acid 1,4 - lactone $\left(\mathrm{IC}_{50}=\right.$ $48.4 \pm 1.25 \mu \mathrm{M})$.

Many $\beta$ - glucuronidase inhibitors such as 8 - hydroxytricetin-7- glucuronide, isovitexin, trihydroxypipecolic acid and scoparic acid A and C, L aspartic acid, tectorigenin and benzothiazoles have been isolated from different plants and some are used clinically (Khan et al., 2002). However, there are no reports of $\beta$ glucuronidase inhibitory activity of compounds isolated from lichens. 
Table 1: Immunomodulatory activities of lobaric acid

\begin{tabular}{|c|c|c|c|}
\hline \multirow{2}{*}{ Compound } & \multicolumn{3}{|c|}{ Immunomodulatory activity $\mathrm{IC}_{50} \pm \mathrm{SEM}(\mu \mathrm{g})$} \\
\hline & $\begin{array}{c}\text { Whole blood } \\
+ \text { luminol }\end{array}$ & $\begin{array}{l}\text { PMN's } \\
+ \text { luminol }\end{array}$ & $\begin{aligned} & \text { PMN's } \\
&+ \text { lucigenin } \\
&\end{aligned}$ \\
\hline Lobaric acid (1) & $37.6 \pm 0.9$ & $<3.1$ & $<3.1$ \\
\hline Ibuprofen & $11.8 \pm 1.87$ & $2.5 \pm 0.6$ & - \\
\hline $\begin{array}{l}\text { Sodium diethyldithio } \\
\text { carbamatetrihydrate }\end{array}$ & - & $1.27 \pm 0.23$ & $8.16 \pm 1.9$ \\
\hline
\end{tabular}

Phosphodiesterase is believed to be involved in a wide variety of processes, such as bone formation, insulin resistance and metastasis of cancer cells. The inhibitors of phosphodiesterase are used in the treatment of some forms of arthritis. Only a few inhibitors have been reported so far, majority of them being of synthetic origin (Ahmad et al., 2003) and none from lichen sources. Lobaric acid showed a significant inhibition of phosphodiesterase enzyme with an $\mathrm{IC}_{50} \pm \mathrm{SEM}(\mu \mathrm{M})$ of a $313.7 \pm 2.2$ when compared with the two standards, $\operatorname{EDTA}\left(\mathrm{IC}_{50}=274.0 \pm 0.1 \mu \mathrm{M}\right)$ and cysteine $\left(\mathrm{IC}_{50}=748.0\right.$ $\pm 0.1 \mu \mathrm{M})$.

Lobaric acid did not show $\alpha$-glucosidase inhibitory activity or any significant inhibition against the urease enzyme.

Immunomodulators are substances capable of interacting with the immune system to up-regulate or down-regulate specific aspects of the host response. Due to the broad application of their action, immunomodulators are becoming very popular in the global natural product based health industry (Yeap et al., 2011). Various disease conditions such as infections, organ transplant rejection, cancer, rheumatoid arthritis, and systemic lupus erythematosus are currently treated with immunomodulating agents (Long et al., 2011). Different immunomodulatory agents have been screened from a variety of plants, including the lichen Thamnolia vermicularis var. subuliformis (Omarsdottir et al., 2007). Lobaric acid was screened over a range of concentrations (3.1-50 $\mu \mathrm{g} / \mathrm{mL})$ for its oxidative burst inhibitory potential. It suppressed both the myeloperoxidase dependant and myeloperoxidase independent ROS production with PMNs at the lowest concentration tested $(3.1 \mu \mathrm{g} / \mathrm{mL})$, when compared with standards ibuprofen and sodium diethyldithiocarbamatetrihydrate (Table 1).

\section{CONCLUSION}

Although acetyl and butyryl-cholinesterases inhibitory activities of acetylated and diacytylated depsidones have been reported (Pejin et al., 2012), this is the first report of these activities of lobaric acid. However, lobaric acid did not show any inhibitory potential against $\alpha$-glucosidase or urease enzymes. In the $\beta$-glucuronidase enzyme inhibitory assay, lobaric acid has shown 12 times higher activity than the available standard D-saccharic acid 1,4lactone further indicating the pharmacological potential of lobaric acid as a lead compound. Even though a few heteroglycans isolated from the lichen Thamnolia vermicularis var. subuliformis (Omarsdottir et al., 2007) have shown potential immunomodulatory activity, this is the first report of the promising immunomodulatory activity of a lichen depsidone. The results presented above make lobaric acid with highly diverse functional groups, such as three carbonyls in the form of keto, ester and acid, phenolic $\mathrm{OH}$ and an ether group, an excellent candidate for future studies with structural optimization.

\section{REFERENCES}

1. Ahmad V.U., Abbasi M.A., Hussain H., Akhtan M.N., Farooq U., Fatima N. \& Choudhary M.I. (2003). Phenolic glycosides from Symplocosracemosa: natural inhibitors of phosphodiesterase I. Phytochemistry 63: $217-220$.

2. Burlando B., Ranzato E., Volante A., Appendino G., Pollastro F. \& Verotta L. (2009). Antiproliferative effects on tumour cells and promotion of keratinocyte wound healing by different lichen compounds. Planta Medica $\mathbf{7 5 :}$ $607-613$.

DOI: http://dx.doi.org/10.1055/s-0029-1185329

3. Ellman G.L., Courtney K.D., Andres V. \& Featherstone R.M. (1961). A new and rapid colorimetric determination of acetylcholinesterase activity. Biochemical Pharmacology 7: $88-95$.

4. Gissurarson S.R., Sigurdsson S.B., Wagner H. \& Ingolfsdottir K. (1997). Effect of lobaric acid on cysteinylleukotriene formation and contractile activity of guinea pig Taenia coli. The Journal of Pharmacology and Experimental Therapeutics 280(2): $770-773$.

5. Gonzilez G.A., Rodriguez-Perez E.M., Conseulelo E., Padron H. \& Barrera J.B. (1992). Chemical constituents of the lichen Sterocaulon azoreum. Zeitschrift fur Naturforschung $C-A$ Journal of Biosciences 47c: 503 - 507. 
6. Helfand S.L., Werkmeister J. \& Roder J.C. (1982). Chemiluminescence response of human natural killer cells: the relationship between target cell binding, chemiluminessence and cytolysis. Journal of Experimental Medicine 156: 492 - 505.

DOI: http://dx.doi.org/10.1084/jem.156.2.492

7. Karunaratne V., Bombuwela K., Kathirgamanathar S., Kumar V., Karunaratne D.N., Ranawana K.B., Wijesundara D.S.A., Weerasooriya A. \& De Silva E.D. (2002). An association between the butterfly, Talicadanyseus and the lichen as evidenced from chemical studies. Current Science 83(6): $741-745$.

8. Karunaratne V., Bombuwela K., Kathirgamanathar S. \& Thadhani V.M. (2005). Lichens: a chemically important biota. Journal of the National Science Foundation of Sri Lanka 33(3): 169 - 186.

9. Karunaratne V., Kathirgamanathar S., Wijesekera A., Wijesundara D.S.A. \& Wolseley P. (2008). Insights into the unique butterfly-lichen association between Talicada nyseus nyseus and Leproloma sipmanianum. Journal of Plant Interactions 3: 25 - 30.

DOI: http://dx.doi.org/10.1080/17429140701740061

10. Kathirgamanathar S., Ratnasooriya W.D., Baekstrom P., Andersen R.J. \& Karunaratne V. (2006). Chemistry and bioactivity of Physciaceae lichens: Pyxine consocians and Heterodermia leucomelos. Pharmacentical Biology 44: $217-220$. DOI: http://dx.doi.org/10.1080/13880200600686624

11. Khan K.M., Shujaat S., Rahat S., Hayat S., Atta-ur-Rahaman $\&$ Choudhary M.I. (2002). $\beta$ - $N$-Cyanoethyl acyl hydrazide derivatives: a new class of $\beta$-glucuronidase inhibitors. Chemistry and Pharmaceutical Bulletin 50: 1443 - 1446. DOI: http://dx.doi.org/10.1248/cpb.50.1443

12. Long M.D., Kappelman M.D. \& Pipkin C.A. (2011). Nonmelanoma skin cancer in inflammatory bowel disease: a review. Inflammatory Bowel Disease 17(6): 1423 - 1427.

13. Majmudar C.Y. et al. (15 authors) (2012). Sekikaic acid and lobaric acid target a dynamic interface of the coactivator $\mathrm{CBP} / \mathrm{p} 300$. Angewandte Chemie International Edition 51(45): 11258 - 11262.

14. Mitrović T., Stamenković S., Cvetković V., Nikolić M., Tošić S. \& Stojičić D. (2011). Lichens as source of versatile bioactive compounds. Biologica Nyssana 2(1): 1 - 6 .

15. Morita H., Tsuchiya T., Kishibe K., Noya S., Shiro M. \& Hirasawa Y. (2009). Antimitotic activity of lobaric acid and a new benzofuran, sakisacaulon A from Stereocaulon sasakii. Bioorganic and Medicinal Chemistry Letters 19 (13): $3679-3681$.
16. Oki Y., Okubo M., Tanaka S., Nakanish K. \& Murase T. (2000). Diabetes mellitus secondary to glycogen storage disease type III. Diabetic Medicine 17: 810 - 812 . DOI: http://dx.doi.org/10.1046/j.1464-5491.2000.00378.x

17. Omarsdottir S., Freysdottir J. \& Olafsdottir E.S. (2007). Immunomodulating polysaccharides from the lichen Thamnolia vermicularis var. subuliformis. Phytomedicine 14(2-3): $179-184$.

DOI: http://dx.doi.org/10.1016/j.phymed.2006.11.012

18. Pejin B., Tommonaro G., Iodice C., Tesevic V. \& Vajs V. (2012). Acetylcholinesterase inhibition activity of acetylated depsidones from Lobaria pulmonaria. Natural Products Research 26(17): 1634 - 1637.

DOI: http://dx.doi.org/10.1080/14786419.2011.585989

19. Stojanovic G., Stojanovic I. \& Smelcerovic A. (2012). Lichen depsidones as potential novel pharmacologically active compounds. Mini-Reviews in Organic Chemistry 9(2): $178-184$. DOI: http://dx.doi.org/10.2174/157019312800604689

20. Thadhani V.M., Choudhary M.I., Sajjad A., Iman O., Siddique H. \& Karunaratne V. (2011). Antioxidant activity of some lichen metabolites. Natural Products Research 25(19): $1827-1837$.

DOI: http://dx.doi.org/10.1080/14786419.2010.529546

21. Thadhani V.M., Choudhary M.I., Khan S. \& Karunaratne V. (2012). Antimicrobial and toxicological activities of some depsides and depsidones. Journal of the National Science Foundation Sri Lanka 40(1): 43 - 48.

DOI: http://dx.doi.org/10.4038/jnsfsr.v40i1.4167

22. Thune P.O. \& Solberg Y.J. (1980). Photosensitivity and allergy to aromatic lichen acids, compositae oleoresins and other plant substances. Contact Dermatitis 6(1):64 - 71 .

23. Weatherburn M.W. (1967). Phenol-hypochlorite reaction for determination of ammonia. Analytical Chemistry 39: $971-974$.

DOI: http://dx.doi.org/10.1021/ac60252a045

24. Williams D.E., Lauren F.L., Whitney J., Singh T.M., McDonald L., Kathirgamanathar S., Karunaratne V. \& Andersen R.J. (2011). Depsidones isolated from the Sri Lankan lichen Parmotrema sp. exhibit selective PLK1 inhibitory activity. Pharmaceutical Biology 49(3): 296 - 301.

DOI: http://dx.doi.org/10.3109/13880209.2010.517540

25. Yeap S.K, Rahman M.B.A., Alitheen N.B., Young Ho W., Omar A.R., Beh B.K. \& Huynh Ky. (2011). Evaluation of immunomodulatory effect: selection of the correct targets for immuno stimulation study. American Journal of Immunology 7(2): $17-23$.

DOI: http://dx.doi.org/10.3844/ajisp.2011.17.23 